\title{
Potato Crop Growth and Yield Response to Different Levels of Nitrogen under Chhattisgarh Plains Agro-climatic Zone
}

\author{
Sanjana Banjare, Gaurav Sharma* and S. K. Verma \\ Department of Horticulture, Indira Gandhi Krishi Vishwavidyalaya, Raipur-492 012, \\ Chhattisgarh, India; gauravhort@gmail.com
}

\begin{abstract}
Field investigation was carried out to study the effect of different nitrogen levels on growth and yield parameters in potato var. Kufri Surya. The experiment was laid out in a randomized block design with treatments consisting of six nitrogen levels replicated four times. Growth parameters like plant height, number of leaves per plant, number of shoot per plant, fresh and dry weight of shoot per plant and yield attributing parameters like number of stolon, fresh and dry weight of tuber per plant increased with an increase in nitrogen levels with maximum values being obtained on application of highest nitrogen level (375 kg N/ha). However, highest values for number of tuber per plant and per plot as well as tuber yield per plot and per hectare was recorded on application of $225 \mathrm{~kg} \mathrm{~N} / \mathrm{ha}$. The highest net returns (Rs. 117323) and maximum B: C ratio (1.42) was recorded on application of $225 \mathrm{~kg} \mathrm{~N} / \mathrm{ha}$.
\end{abstract}

Keywords: B:C Ratio, Nitrogen Level, Potato, Tuber Yield

\section{Introduction}

Potato (Solanum tuberosum L.) belongs to family Solanaceae and is one of the most important vegetable cum starch supplying crop having high production per unit area per unit time. Potato, an underground tuber occupies prime position among the cash crops in India. Potatoes are rich source of vitamins, especially $\mathrm{C}$ and $\mathrm{B}$ and also minerals. Tubers contain $70-80 \%$ water, $20.6 \%$ carbohydrate, $2.1 \%$ protein, $0.3 \%$ fat, $1.1 \%$ crude fibre and $0.9 \% a^{a s h}{ }^{1}$. Among major food crops, potato produces the highest dry matter and edible protein per unit area and time. It can fulfill the requirement of food for human consumption to a greater extent.

India is the second largest producer of potato in the world after China, with cultivation in an area of about $2.02 \mathrm{~m}$ ha and production of 46 million metric tons ${ }^{2}$. Potato is grown almost in all the states of India except Kerala. In Chhattisgarh, it is cultivated in an area of about 37,888 ha with a production of 5.5 lakh metric tons ${ }^{3}$. Due to its suitability and high returns, the area of potato is increasing every year in this state. In Chhattisgarh, potato is mainly cultivated in Sarguja, Raigarh, Jashpur, Bilaspur and Raipur districts in rabi season except in Mainpat and Samaryapat hills of Chhattisgarh, where this crop is grown during kharif and rabi season both.

The growth, development and yield of potato are mainly governed by availability of major nutrients required for its cultivation. Nitrogen is the first limiting factor for potato crop which improves vegetative growth and invariably increases yield, tuber per plant, tuber size as well as tuber numbers ${ }^{4-5}$. However, in the eastern plains of India including the state of Chhattisgarh, unbalanced fertilization in favour of $\mathrm{N}$ application is quite common among farmers ${ }^{6}$. Over application of $\mathrm{N}$ is a serious problem leading to large nitrogen losses through leaching and enrichment of reactive $\mathrm{N}$ constituent in the atmosphere, soil and water with consequent damage to ecosystem ${ }^{7}$. Moreover, excessive nitrogen leads to poor tuber quality and delayed crop maturity, whereas, nitrogen deficiency usually results in poor vegetative growth and low yield. Therefore, there is a need to optimize nitrogen dose

${ }^{*}$ Author for correspondence 
under Chhattisgarh plains agro-climatic zone for higher yield with high $\mathrm{N}$ use efficiency in potato. Keeping these points in view, the present investigation was undertaken to standardize the dose of nitrogen and its judicious use in potato crop for Chhattisgarh plains agro-climatic zone in order to increase production.

\section{Materials and Methods}

The present investigation was carried out at the Department of Horticulture, Indira Gandhi Krishi Vishwavidyalaya, Raipur, Chhattisgarh during the rabi season of 2011-12. Raipur, the place of investigation, is situated in central part of Chhattisgarh and lies at 2104' N Latitude and $81035^{\prime}$ E Longitude with an altitude of $298.56 \mathrm{~m}$ above mean sea level. The average annual rainfall of the region is around $1400 \mathrm{~mm}$ and about 90 to 95 percent of this amount is received during southwest monsoon season (June-October). The experiment was laid out in randomized block design with six treatments consisting of different levels of nitrogen viz., 0 (control), 75, 150, 225, 300 and $375 \mathrm{~kg} / \mathrm{ha}$ which were replicated four times. Nitrogen was applied in the form of urea $(46 \% \mathrm{~N})$. Recommended dose of phosphorus and potassium i.e. $100 \mathrm{~kg} / \mathrm{ha}$ of each was applied. The test variety used was Kufri Surya planted on ridges of $60 \mathrm{~cm}$ apart with a spacing of $20 \mathrm{~cm}$. The soil of experimental field was clayey loam with low level of nitrogen $(220 \mathrm{~kg} / \mathrm{ha})$, medium phosphorus (14 kg/ha), and high potash $(354 \mathrm{~kg} / \mathrm{ha})$. Well rotten FYM was spread in all the plots in equal quantity @ 250 q/ha and was mixed with the soil. Full dose of phosphorus and potassium @ $100 \mathrm{~kg} / \mathrm{ha}$ was applied through single super phosphate and muriate of potash, respectively as basal dose at the time of planting, whereas nitrogen was applied in each plot in split doses as per the treatments. Half dose of the nitrogen of each treatment was applied through urea as basal dressing and remaining half dose was applied at 30 days after planting. All the three fertilizers used for basal dressing were mixed before application and was applied in the middle of ridges before planting the tubers. Thirty days after planting the remaining dose of nitrogen was applied through urea as top dressing just before earthing up. Earthing up was done at 30 days after planting (DAP). Weeding was done at the time of earthing to remove the weeds. Eight irrigations were provided during the entire crop growth period. Although, irrigation was given by flood irrigation method, but the precaution was taken that only $1 / 2$ to $3 / 4^{\text {th }}$ ridges be wet while irrigating the field. All the recommended package and practices were followed to raise a healthy crop. Haulm cutting of potato crop was done manually at $90 \mathrm{DAP}$ and then digging of tuber was done 10 days after haulm cutting by using spade. After harvesting the potato, tubers were graded into four groups for each plot in all the replication on the basis of tuber weight as $<25 \mathrm{~g}, 25-50 \mathrm{~g}, 51-75 \mathrm{~g}$ and $>75 \mathrm{~g}$ and weighed separately to record yield.

\section{Results and Discussion}

\subsection{Growth Parameters}

Data presented on growth parameters in Table 1 reveals that the treatment effect was found to be significantly different for plant height. Increasing trend in case of plant height was observed with the increase in nitrogen levels. At 45, 60 and 75 DAP, similar trend was observed for plant height with maximum plant height $(44.25,47.75$ and $48.00 \mathrm{~cm}$, respectively) recorded under $375 \mathrm{~kg} \mathrm{~N} / \mathrm{ha}$ but having at par effect with $150 \mathrm{~kg} \mathrm{~N} / \mathrm{ha}, 225 \mathrm{~kg} \mathrm{~N} / \mathrm{ha}$ and $300 \mathrm{~kg} \mathrm{~N} / \mathrm{ha}$. Irrespective of days after planting, similar trend was followed with respect to number of leaves per plant. In general, an increase in nitrogen influenced the number of leaves per plant. Significantly maximum number of leaves were found on application of $375 \mathrm{~kg} \mathrm{~N} / \mathrm{ha}$ followed by $150 \mathrm{~kg} \mathrm{~N} / \mathrm{ha}, 225 \mathrm{~kg} \mathrm{~N} / \mathrm{ha}$ and $300 \mathrm{~kg} \mathrm{~N} / \mathrm{ha}$, all having statistically equal effect. Maximum number of leaves recorded at 45, 60 and 75 DAP were $46.25,48.00$ and 49.75 respectively. These results are in the line with the findings of Pandey et al. ${ }^{8}$ and Bose et al. ${ }^{9}$ with respect to number of shoot per plant, at 45 and 60 DAP, no significant difference among the treatments was found. At 75 DAP, significantly maximum number of shoot per plant (6.50) was recorded with nitrogen level $375 \mathrm{~kg} \mathrm{~N} / \mathrm{ha}$ which was having at par effect with treatments $150 \mathrm{~kg} \mathrm{~N} / \mathrm{ha}$ and $300 \mathrm{~kg} \mathrm{~N} / \mathrm{ha}$. The increase in plant height, number of leaves and shoot with increase in nitrogen levels may be due to the fact that higher nitrogen concentration stimulated the assimilation of carbohydrates and protein, which in turn enhanced cell division and formation of more tissues that resulted in enhanced vegetative growth of the plant ${ }^{10}$ and also in the production of stem and axillary branches.

In case of fresh weight of shoot per plant, beyond $75 \mathrm{~kg} \mathrm{~N} / \mathrm{ha}$ there was marked response of nitrogen for enhancing the fresh weight of shoot with maximum being recorded under $300 \mathrm{~kg} \mathrm{~N} / \mathrm{ha}(297.50 \mathrm{~g})$. Maximum dry weight of shoot per plant $(28.00 \mathrm{~g})$ was noted in the treatment $300 \mathrm{~kg} \mathrm{~N} / \mathrm{ha}$. Dry weight of shoot per plant was directly related with fresh weight of shoot per plant. An application of higher dose of nitrogen resulted in increase in the plant height and foliage thereby increasing the fresh and dry weight of shoot per plant with increase 
Table 1. Effect of nitrogen levels on vegetative parameters of potato

\begin{tabular}{|c|c|c|c|c|c|c|c|c|c|c|c|}
\hline \multirow{2}{*}{$\begin{array}{r}\text { Nitrogen } \\
\text { levels }\end{array}$} & \multicolumn{3}{|c|}{ Plant height $(\mathrm{cm})$} & \multicolumn{3}{|c|}{ Number of leaves per plant } & \multicolumn{3}{|c|}{ Number of shoot per plant } & \multirow{2}{*}{$\begin{array}{c}\text { Fresh } \\
\text { wt. of } \\
\text { shoot } \\
\text { (g) }\end{array}$} & \multirow{2}{*}{$\begin{array}{l}\text { Dry wt. of } \\
\text { shoot (g) }\end{array}$} \\
\hline & 45 DAP & 60 DAP & 75 DAP & 45 DAP & 60 DAP & 75 DAP & 40 DAP & 60 DAP & 75 DAP & & \\
\hline $0 \mathrm{~kg} / \mathrm{ha}$ & 30.53 & 38.50 & 41.50 & 36.75 & 39.50 & 43.00 & 4.50 & 4.50 & 4.50 & 135.75 & 13.00 \\
\hline $75 \mathrm{~kg} / \mathrm{ha}$ & 34.75 & 40.50 & 42.25 & 37.25 & 41.50 & 44.50 & 4.50 & 4.75 & 5.00 & 194.25 & 19.25 \\
\hline $150 \mathrm{~kg} / \mathrm{ha}$ & 38.85 & 43.25 & 46.75 & 45.00 & 45.25 & 45.25 & 5.00 & 5.75 & 6.00 & 280.75 & 27.00 \\
\hline $225 \mathrm{~kg} / \mathrm{ha}$ & 41.80 & 45.75 & 47.25 & 43.00 & 46.50 & 48.50 & 4.75 & 4.75 & 5.00 & 288.50 & 27.75 \\
\hline $300 \mathrm{~kg} / \mathrm{ha}$ & 41.25 & 44.75 & 47.25 & 42.25 & 45.00 & 48.75 & 4.50 & 5.00 & 6.00 & 297.50 & 28.00 \\
\hline $375 \mathrm{~kg} / \mathrm{ha}$ & 44.25 & 47.75 & 48.00 & 46.25 & 48.00 & 49.75 & 5.50 & 5.75 & 6.50 & 288.50 & 27.50 \\
\hline $\begin{array}{r}C D \\
(p=0.05)\end{array}$ & 6.69 & 5.99 & 4.78 & 5.49 & 6.89 & 4.66 & NS & NS & 0.93 & 41.89 & 3.52 \\
\hline
\end{tabular}

in nitrogen levels. Also, nitrogen fertilizer increased the leaf area which increases the amount of solar radiation intercepted and consequently, increases dry matter production of different plant parts ${ }^{11}$. Present findings are in agreement with the previous reports where increase in dry weight has been recorded with an increase in nitrogen level ${ }^{11-12}$.

\subsection{Yield and Yield Attributing Parameters}

On the perusal of yield attributing data presented in Table 2, it is evident that the maximum number of stolon per plant (16.75) was recorded under the treatment $375 \mathrm{~kg} \mathrm{~N} / \mathrm{ha}$ which was statistically similar to $300 \mathrm{~kg} \mathrm{~N} / \mathrm{ha}, 225 \mathrm{~kg} \mathrm{~N} / \mathrm{ha}$ and $150 \mathrm{~kg} \mathrm{~N} / \mathrm{ha}$. The minimum number of stolon per plant (11.25) was counted in the treatment $0 \mathrm{~kg} \mathrm{~N} / \mathrm{ha}$. At harvest, fresh weight of tuber per plant ranged from minimum of $365 \mathrm{~g}$ to maximum of $543 \mathrm{~g}$. Significantly maximum fresh weight of tuber per plant (543 g) over control was obtained in the treatment $375 \mathrm{~kg} \mathrm{~N} / \mathrm{ha}$. The maximum dry weight of tuber per plant $(21.08 \mathrm{~g})$ was noted on application of $375 \mathrm{~kg} \mathrm{~N} / \mathrm{ha}$. However, all the levels of nitrogen except $75 \mathrm{~kg}$ N/ha were observed to be significantly superior over $0 \mathrm{~kg} \mathrm{~N} / \mathrm{ha}$, but were having at par effect on dry weight of tuber amongst themselves. The increase in dry matter percentage with nitrogen application might be due to the fact that higher doses of nitrogen might have helped in the production of photosynthesis, resulting in the accumulation of dry matter to be higher in the storage part i.e. tuber ${ }^{13}$. These results have been found to be in conformity with the findings of Sinha ${ }^{14}$ and Etemad and Sarajuoghi ${ }^{15}$. The highest number of tuber per plant (8.14) was recorded with $225 \mathrm{~kg} \mathrm{~N} / \mathrm{ha}$ which was having statistically equal effect with rest of the treatments but significantly superior over control. The observed tuber number increase in response to $\mathrm{N}$ fertilization could be attributed to an increase in stolon number through its effect on gibberellin biosynthesis in the potato plant. Yenagi et al. ${ }^{16}$ also reported similar findings. Data regarding to grade wise number of tuber per plot revealed that this attribute was significantly affected by the nitrogen levels only for grades 50-75 $\mathrm{g}$ and $>75 \mathrm{~g}$ tuber. The highest number of tuber per plot (103.00) for grade 50-75 g tuber was obtained under $225 \mathrm{~kg} \mathrm{~N} / \mathrm{ha}$ followed by $300 \mathrm{~kg} \mathrm{~N} / \mathrm{ha}, 375 \mathrm{~kg} \mathrm{~N} / \mathrm{ha}, 150 \mathrm{~kg} \mathrm{~N} / \mathrm{ha}$ and $75 \mathrm{~kg} \mathrm{~N} / \mathrm{ha}$, all significantly superior to control. Similar trend was observed in the grade $>75 \mathrm{~g}$ tuber, wherein highest number of tuber per plot (135.00) was noticed in $225 \mathrm{~kg} \mathrm{~N} /$ ha which was having at par effect with $300 \mathrm{~kg} \mathrm{~N} / \mathrm{ha}$ and $375 \mathrm{~kg} \mathrm{~N} /$ ha but significantly superior to treatment $150 \mathrm{~kg} \mathrm{~N} / \mathrm{ha}$ and $75 \mathrm{~kg} \mathrm{~N} / \mathrm{ha}$. The present results are in conformity with the findings of Chettri et $\mathrm{al}^{17}$. In case of total number of tuber per plot, highest number of tuber (364.00) was noted in $225 \mathrm{~kg} \mathrm{~N} / \mathrm{ha}$ which was having statistically equal effect with $300 \mathrm{~kg} \mathrm{~N} / \mathrm{ha}$ and $375 \mathrm{~kg} \mathrm{~N} / \mathrm{ha}$.

With regard to the yield data, presented in Table 3, it can be inferred that highest tuber yield per plot $(0.45 \mathrm{~kg})$ in the grade $0-25 \mathrm{~g}$ was obtained under $375 \mathrm{~kg} \mathrm{~N} / \mathrm{ha}$, whereas in case of 50-75 $\mathrm{g}$ and $>75 \mathrm{~g}$ grade tuber, the highest yield per plot ( $7.25 \mathrm{~kg}$ and $12.63 \mathrm{~kg}$, respectively) was obtained under $225 \mathrm{~kg} \mathrm{~N} / \mathrm{ha}$ which had at par effect with all the other treatments, but significantly superior over control. In case of the 25-50 g grade tuber, all the treatments exerted no significant effect on tuber yield. Belanger et al. ${ }^{18}$ found that application of appropriate amounts of nitrogen resulted in more favorable effects than higher rates. Zelalem et al. ${ }^{19}$ also observed that for higher tuber yield optimum nitrogen management was important. Similarly, 
Table 2. Effect of nitrogen levels on yield attributing parameters of potato

\begin{tabular}{|c|c|c|c|c|c|c|c|c|c|}
\hline \multirow{2}{*}{$\begin{array}{r}\text { Nitrogen } \\
\text { levels }\end{array}$} & \multirow{2}{*}{$\begin{array}{l}\text { No. of } \\
\text { stolon per } \\
\text { plant }\end{array}$} & \multirow{2}{*}{$\begin{array}{l}\text { Fresh wt. } \\
\text { of tuber } \\
\text { per plant } \\
\quad(\mathrm{g})\end{array}$} & \multirow{2}{*}{$\begin{array}{l}\text { Dry wt. of } \\
\text { tuber per } \\
\text { plant }(g)\end{array}$} & \multirow{2}{*}{$\begin{array}{l}\text { No. of } \\
\text { tuber per } \\
\text { plant at } \\
\text { harvest }\end{array}$} & \multicolumn{4}{|c|}{ Grade-wise number of tuber per plot } & \multirow{2}{*}{$\begin{array}{c}\text { Total no. } \\
\text { of tuber } \\
\text { per plot at } \\
\text { harvest }\end{array}$} \\
\hline & & & & & $0-25 \mathrm{~g}$ & $25-50 \mathrm{~g}$ & $50-75 \mathrm{~g}$ & $>75 \mathrm{~g}$ & \\
\hline $0 \mathrm{~kg} / \mathrm{ha}$ & 11.25 & 365 & 19.26 & 6.18 & 31.00 & 70.00 & 61.00 & 70.00 & 232.00 \\
\hline $75 \mathrm{~kg} / \mathrm{ha}$ & 12.50 & 478 & 19.90 & 7.26 & 38.00 & 76.00 & 89.00 & 85.00 & 288.00 \\
\hline $150 \mathrm{~kg} / \mathrm{ha}$ & 13.75 & 490 & 20.02 & 7.40 & 44.00 & 74.00 & 90.00 & 100.00 & 308.00 \\
\hline $225 \mathrm{~kg} / \mathrm{ha}$ & 14.25 & 528 & 21.03 & 8.14 & 42.00 & 84.00 & 103.00 & 135.00 & 364.00 \\
\hline $300 \mathrm{~kg} / \mathrm{ha}$ & 16.25 & 500 & 20.87 & 7.87 & 42.00 & 72.00 & 95.00 & 120.00 & 329.00 \\
\hline $375 \mathrm{~kg} / \mathrm{ha}$ & 16.75 & 543 & 21.08 & 7.58 & 31.00 & 77.00 & 94.00 & 118.00 & 320.00 \\
\hline $\begin{array}{r}C D \\
(p=0.05)\end{array}$ & 3.1 & 91.69 & 1.59 & 1.19 & NS & NS & 21.53 & 25.16 & 45.13 \\
\hline
\end{tabular}

Table 3. Effect of nitrogen levels on yield parameters of potato

\begin{tabular}{|c|c|c|c|c|c|c|c|c|c|c|}
\hline \multirow{2}{*}{$\begin{array}{r}\text { Nitrogen } \\
\text { levels }\end{array}$} & \multicolumn{4}{|c|}{ Grade-wise yield of tuber (kg/plot) } & \multicolumn{3}{|c|}{ Tuber yield (kg/plot) } & \multicolumn{3}{|c|}{ Tuber yield $(\mathrm{q} / \mathrm{ha})$} \\
\hline & $0-25 g$ & $25-50 \mathrm{~g}$ & $50-75 g$ & $>75 \mathrm{~g}$ & $M^{*}$ & $\mathrm{U}^{* *}$ & Total & $\mathbf{M}^{\star}$ & $\mathrm{U}^{* *}$ & Total \\
\hline $0 \mathrm{~kg} / \mathrm{ha}$ & 0.22 & 3.38 & 4.53 & 6.56 & 13.79 & 0.90 & 14.69 & 143.64 & 9.37 & 153.01 \\
\hline $75 \mathrm{~kg} / \mathrm{ha}$ & 0.23 & 3.51 & 6.28 & 8.93 & 18.20 & 0.75 & 18.95 & 189.58 & 7.81 & 197.39 \\
\hline $150 \mathrm{~kg} / \mathrm{ha}$ & 0.34 & 4.28 & 6.97 & 12.49 & 23.53 & 0.55 & 24.08 & 245.10 & 5.72 & 250.82 \\
\hline $225 \mathrm{~kg} / \mathrm{ha}$ & 0.41 & 3.84 & 7.25 & 12.63 & 23.97 & 0.16 & 24.13 & 249.68 & 1.66 & 251.34 \\
\hline $300 \mathrm{~kg} / \mathrm{ha}$ & 0.42 & 3.33 & 7.18 & 11.05 & 21.78 & 0.20 & 21.98 & 226.87 & 2.08 & 228.95 \\
\hline $375 \mathrm{~kg} / \mathrm{ha}$ & 0.45 & 3.12 & 7.08 & 11.30 & 21.55 & 0.40 & 21.95 & 224.47 & 4.16 & 228.63 \\
\hline $\begin{array}{r}\mathrm{CD} \\
(\mathrm{p}=0.05)\end{array}$ & 0.11 & NS & 2.25 & 3.88 & 6.74 & 0.45 & 5.77 & 48.13 & 2.43 & 46.59 \\
\hline
\end{tabular}

$\mathbf{M}^{\star}=$ Marketable; $\mathrm{U}^{\star *}=$ Unmarketable

the highest yield of marketable tuber $(23.97 \mathrm{~kg} / \mathrm{plot})$ was recorded on the application of $225 \mathrm{~kg} \mathrm{~N} / \mathrm{ha}$ whereas, highest unmarketable yield of tuber $(0.90 \mathrm{~kg} / \mathrm{plot})$ was recorded with $0 \mathrm{~kg} \mathrm{~N} /$ ha which was observed to have at par effect with $75 \mathrm{~kg} \mathrm{~N} / \mathrm{ha}$ and $150 \mathrm{~kg} \mathrm{~N} / \mathrm{ha}$. The highest total tuber yield $(24.13 \mathrm{~kg} / \mathrm{plot})$ was recorded in $225 \mathrm{~kg} \mathrm{~N} / \mathrm{ha}$. However, no significant difference was observed between the treatments $225 \mathrm{~kg} \mathrm{~N} / \mathrm{ha}$ and other treatments viz., $150 \mathrm{~kg} \mathrm{~N} / \mathrm{ha}, 300 \mathrm{~kg} \mathrm{~N} / \mathrm{ha}$ and $375 \mathrm{~kg} \mathrm{~N} / \mathrm{ha}$ for this attribute. Reiter et al. ${ }^{20}$ also observed that substantial inorganic $\mathrm{N}$ fertilizer sources are necessary for optimal production. The highest yield of marketable tuber $(249.68 \mathrm{q} / \mathrm{ha})$ as well as total tuber yield ( $251.34 \mathrm{q} / \mathrm{ha})$ was recorded under $225 \mathrm{~kg} \mathrm{~N} / \mathrm{ha}$. However, no significant difference was observed between $225 \mathrm{~kg} \mathrm{~N} / \mathrm{ha}$ and $150 \mathrm{~kg} \mathrm{~N} / \mathrm{ha}$, $300 \mathrm{~kg} \mathrm{~N} / \mathrm{ha}$ and $375 \mathrm{~kg} \mathrm{~N} / \mathrm{ha}$. The highest unmarketable tuber yield was recorded with the lowest nitrogen level w $0 \mathrm{~kg} \mathrm{~N} / \mathrm{ha}$, which was at par with $75 \mathrm{~kg} \mathrm{~N} / \mathrm{ha}$. A decrease in unmarketable yield was observed with higher levels of nitrogen. Higher yield obtained with application of higher dose of nitrogen would have helped in increase in tuberization as well as increased duration of tuber bulking which would have resulted in higher production ${ }^{21}$. Moreover, with increasing nitrogen application, number of stolon, number of tuber and consequently yield were increased ${ }^{22}$. Marguerite et al..$^{23}$ and Maiti et al. ${ }^{24}$ revealed that tuber yield per unit area increased with increasing nitrogen fertilizer up to a suitable level only. Cost of cultivation per hectare (Table 4) was maximum (Rs.84255) in treatment $375 \mathrm{~kg} \mathrm{~N} / \mathrm{ha}$ whereas, the lowest cost of cultivation (Rs.79666) was found in treatment with no nitrogen application. However, the maximum gross income (Rs.199744) and net income (Rs.117323) was obtained with $225 \mathrm{~kg} \mathrm{~N} / \mathrm{ha}$. The benefit cost ratio 
ranged from 0.44 to 1.42 depending on the different levels of nitrogen. It was found to be highest (1.42) under treatment $225 \mathrm{~kg} \mathrm{~N} / \mathrm{ha}$.

Table 4. Economics, net return and B:C ratio of potato crops due to different $\mathrm{N}$ levels under Chhattisgarh plains

\begin{tabular}{rcccc}
\hline $\begin{array}{r}\text { Nitrogen } \\
\text { levels }\end{array}$ & $\begin{array}{c}\text { Cost of } \\
\text { cultivation } \\
\text { (Rs/ha) }\end{array}$ & $\begin{array}{c}\text { Gross } \\
\text { return } \\
\text { (Rs/ha) }\end{array}$ & $\begin{array}{c}\text { Net } \\
\text { return } \\
\text { (Rs/ha) }\end{array}$ & $\begin{array}{c}\text { B:C } \\
\text { ratio }\end{array}$ \\
\hline $0 \mathrm{~kg} / \mathrm{ha}$ & 79666 & 114912 & 35245 & 0.44 \\
$75 \mathrm{~kg} / \mathrm{ha}$ & 80584 & 151664 & 71079 & 0.88 \\
$150 \mathrm{~kg} / \mathrm{ha}$ & 81502 & 196080 & 114577 & 1.40 \\
$225 \mathrm{~kg} / \mathrm{ha}$ & 82420 & 199744 & 117323 & 1.42 \\
$300 \mathrm{~kg} / \mathrm{ha}$ & 83338 & 181496 & 98157 & 1.17 \\
$375 \mathrm{~kg} / \mathrm{ha}$ & 84255 & 179576 & 95320 & 1.13 \\
\hline
\end{tabular}

\section{Conclusion}

It can be inferred from the present findings that, optimum nitrogen application is essential to improve potato tuber yield. Although with the increase in nitrogen levels, vegetative parameters of crop growth increased with maximum values achieved on application of $375 \mathrm{~kg} \mathrm{~N} /$ ha but application of $225 \mathrm{~kg} \mathrm{~N} /$ ha proved to be superior for obtaining higher yield and yield attributing characters. Thus, application of optimum dose of $225 \mathrm{~kg}$ $\mathrm{N} / \mathrm{h}$ a was observed to be superior in terms of yield, as well as more profitable and can, therefore, be economically recommended for cultivation of potato variety Kufri Surya under Chhattisgarh plains agro-climatic zone.

\section{References}

1. Banu S, Thiyagarajan TM, Malarvizhi P. Effect of graded levels of fertilizers on quality aspects of potato. Potato J. 2007; 34(3-4): 242-44.

2. National Horticulture Board. Area and production statistics [internet]. 2014 [cited 2014 July 12]. Available from: http://nhb.gov.in/area\%20_production.html

3. Chhattisgarh Horticulture. Statistics: At a glance [internet]. 2014 [cited 2014 July 12]. Available from: http://www. cghorticulture.gov.in/statistics.htm

4. Anand S, Krishnappa KS. Effect of different levels of $\mathrm{N}$ and $\mathrm{K}$ on the growth, yield and quality of potato in sandy loam soil. Mysore J Agric Sci. 1988; 22: 483-88.

5. Bhowmik NN, Dandapat A. Studies on yield parameters and yield of potato (Solanum tuberosum L.) cultivars under varying levels of nitrogen. Indian Agric.1991; 35(1): 21-6.

6. Singh SK, Rai RP. The potato crop in Bihar: status and future challenges. Electronic Int Fert Corresp. 2011; 27: 1-8.

7. Singh SK, Lal SS. Effect of potassium nutrition on potato yield, quality and nutrient use efficiency under varied levels of nitrogen application. Potato J. 2012; 39(2): 155-65.
8. Pandey SK, Kumar P, Singh BP, Singh SV, Kumar D. Effect of nitrogen rate on growth, yield, economics and crisps quality of Indian potato processing cultivars. Potato Res. 2007; 50(2): 143-55.

9. Bose US, Bisen A and Nayak S. Effect of different levels of nitrogen and potassium on growth and yield of potato (Solanum tuberosum L.). Green Farming. 2008; 2(1): 6-17.

10. Anabousi OAN, Hattar BI, Sawwan MA. Effect of rate and source of nitrogen on growth, yield and quality of potato. Dirasat Agric Sci. 1997; 24(2): 242-59.

11. Krishnappa KS. Effect of fertilizer applications on dry matter and $\mathrm{N}, \mathrm{P}$ and $\mathrm{K}$ accumulation in the potato at different stages of growth. Mysore J Agri Sci. 1989; 23:349-54.

12. Vaezzadeh $M$, Naderidarbaghshahi $M$. The effect of various nitrogen fertilizer amounts on yield and nitrate accumulation in tubers of two potato cultivars in cold regions of Isfahan (Iran). Int J Agri Crop Sci. 2012; 4(22): 1688-91.

13. Jha KK, Jha AK, Deepshikha, Bedia HT. Quality of potato (Solanum tuberosum L.) tubers as affected by varieties and NPK levels. Int J Tropical Agric. 2008; 26(1-2): 271-72.

14. Sinha B. Influence of nitrogen levels on growth and tuber yield in potato [M. Sc. (Ag) Thesis]. Raipur: IGKV; 2007.

15. Etemad B, Sarajuoghi M. Study of the effect of different levels and application timing of nitrogen fertilizer on yield and number of potato tuber. Annals of Biological Res. 2012; 3(3):1385-87.

16. Yenagi BS, Meli SS, Angali SS. Response of potato to spacing, planting dates and nitrogen fertilization under rain-fed conditions. Karnataka J Agric Sci. 2005; 18(2):492-93.

17. Chettri M, Thapa U. Integrated nutrient management with farm yard manure on potato (Solanum tuberosum L.) under gangetic plains of West Bengal. Environ Ecol. 2004; 22(4):766-69.

18. Belanger G, Walsh JR, Richard JE, Milburn PH, Ziadi N. Yield response of two potato cultivars to supplemental irrigation and $\mathrm{N}$ fertilization in New Brunsick. Amer J Potato Res. 2000; 77:11-21.

19. Zelalem A, Tekalign T, Nigussie, D. Response of potato (Solanum tuberosum L.) to different rates of nitrogen and phosphorus fertilization on vertisols. African J Plant Sci. 2009; 3(2):16-24.

20. Reiter MS, Rideout SL, Freeman JH. Nitrogen fertilizer and growth regulator impacts on tuber deformity, rot, and yield for russet potatoes. Int J Agron. 2012; 1-7.

21. Kotsyuk VI. Using statistical methods for estimating the effect of fertilizers on potato productivity in the kol'skoi subarctic region. Agrokhinya. 1995; 12:76-88.

22. Zabihi R, Jamaati S, Khayatnezhad M, Gholamin R. Quantitative and Qualitative yield of potato tuber by use of nitrogen fertilizer and plant density. American-Eurasian J Agric Environ Sci. 2010; 9(3):310-18.

23. Marguerite O, Jean-Pierre G, Jean-Francois L. Threshold value for chlorophyll meter as decision tool for nitrogen management of potato. Agron J. 2006; 98:496-506.

24. Maiti S, Banerjee H, Patra T, Pal S. Effect of nitrogen and phosphorus on the growth and tuber yield of potato in gangetic plains of West Bengal. J Interacademicia. 2004; 8(4): 555-58. 